\title{
Protected areas in the North Sea: an absolute need for future marine research
}

\author{
H. J. Lindeboom \\ Netherlands Institute for Sea Research; P.O. Box 59, 1790 AB Den Burg, Texel, \\ The Netherlands
}

\begin{abstract}
There are many signals that different human activities affect the marine ecosystem on local and sometimes regional scales. There is evidence that in the Dutch sector of the North Sea at least 25 species have decreased tremendously in numbers or have totally disappeared. But what has caused their disappearance: fisheries, pollution, eutrophication, climatic changes, or a combination of causes? On the Dutch Continental Shelf, the fisheries are now so intensive that every square metre is trawled, on an average, once to twice a year. Furthermore, it has been shown that trawling causes direct damage to the marine ecosystem. This indicates that the "natural" North Sea ecosystem we are studying is already a heavily influenced system. And what is the value of data on the diversity and production of benthic animals, if the research area has been raked by beamtrawl gear an unknown amount of times before sampling? To be able to study the natural trends in the marine ecosystem, or to answer the question which human activity has most influenced the ecosystem, there is an absolute and immediate need for protected areas to be established. The size of the protected areas must be determined by the behaviour of that species characteristic for the area. In such areas, where fisheries and local pollution would be forbidden or very limited, scientific research into the species composition and age distribution of different populations should be carried out and trends should be established.
\end{abstract}

\section{INTRODUCTION}

Over the last few decades, the sea has been sending out more and more signals that something is changing. Long-term variations in phytoplankton and zooplankton have been reported from the continuous plankton recorder studies (Aebisher et al., 1990). In the early ' 80 s, anoxic circumstances occurred in the German Bight (Gerlach, 1990). The late '80s brought the blooming of Chrysochromulina polylepis in Skandinavian waters (Nielsen \& Richardson, 1989). For years, hardly any dolphins or porpoises have been found near the Dutch coast. In the late ' 70 s and early ' 80 s, in the entire North Sea the catching of herring was totally banned, due to its scarcity. Although the herring returned, soon afterwards it was the mackerel's turn, and now the cod is declining (Daan, 1989; Daan et al., 1990a). The blue tuna and the greater weever have almost disappeared from the North Sea (Daan, 1989). The age composition of the dragonet Callionymus lyra, a non-commercial fish species, changed between 1950 and 1980 (van der Veer et al., 1990). Nowadays, rays and sharks are hardly found in the Dutch part of the North Sea (de Vooys et al., 1991). Bergman et al. (1991) reported that in this area at least 10 benthic species have substantially decreased in numbers or have totally disappeared. On the other hand, several bird species have increased in numbers. 
Although there is little doubt about the occurrence of these changes, the causes are still very disputable. Climatic changes, eutrophication, pollution and fisheries are the most posited explanations (Lindeboom, 1989; Corten, 1990). However, in many cases the cause-effect relationship cannot be scientifically founded. And this is becoming more and more of a problem, especially for management purposes. In the field, both natural and anthropogenic causes can have the same effect, e.g. pollutants, fisheries and climate change may influence certain populations. What is the actual cause, and what can management effectively do?

This paper will provide arguments that the establishment of protected areas in the North Sea is absolutely necessary for scientific studies on the effects of fisheries versus eutrophication, pollution or climate change. Furthermore, if we want to study the longterm effects of fisheries, reference areas are a prerequisite. And what is the scientific value of benthic monitoring data, if our sampling stations are raked by beamtrawl gear 0 to 30 times per year?

\section{SIGNALS FROM THE ECOSYSTEM}

There are many signals that fisheries seriously affect the marine ecosystem. For fish species with a commercial value, the changes have been well documented (Daan et al., 1990a). In the North Sea, the stocks of herring, mackerel, sole and, more recently, cod have shown tremendous declines. For several other species, more irregular patterns have been reported. Although it has been indicated that changes in hydrography could also explain some of the changes (Corten, 1990), exploitation, especially in the case of overfishing, clearly influences the biomass of fish stocks (Daan, 1989).

For species with less or no commercial value, the data on changes in their occurrence in the North Sea are much more scarce and often not well documented. At the Netherlands Institute for Sea Research, a registration has been kept of rare fish species caught between 52 and $55^{\circ} \mathrm{N}$ and 3 and $7^{\circ} \mathrm{E}$ - from 1930 up to the present time. De Vooys et al. (1991) have reported these data for 16 fish species. They concluded that the occurrence of the following species was probably negatively influenced by fishery: skate (Raja batis), stingray (Dasyatis pastinaca), dogfish (Scyliorhinus canicula), smooth hound (Mustelus mustelis), angler (Lopius piscatorius), and greater weever (Trachinus draco). The possible effect of the beamtrawl and increased motor power on the number of fish caught since their introduction is demonstrated in Figure 1. This Figure gives the principal component analyses of the change in numbers of fish caught between 1930 and 1990 . The change after the early 'sixties can be explained by the increasing fishing intensity: an initial increase in the numbers caught is followed by a solid decrease. Rays and sharks are vulnerable to fishery intensity because a close relationship exists between their stock and reproduction. Elasmobranchs have a slow growth and a low level of reproduction (rays ca 100 egg capsules per year, sharks far fewer). Apparently, the number of young is too small to maintain the stock. This conclusion is confirmed by the landings of rays caught in the North Sea (de Vooys et al., 1991).

The occurrence of other species, such as tadpole fish (Raniceps raninus), electric ray (Torpedo nobiliana) and conger (Conger conger), also fluctuates, but their pattern seems more related to other causes.

So far, our understanding of the long-term changes in the ecosystem in relationship 


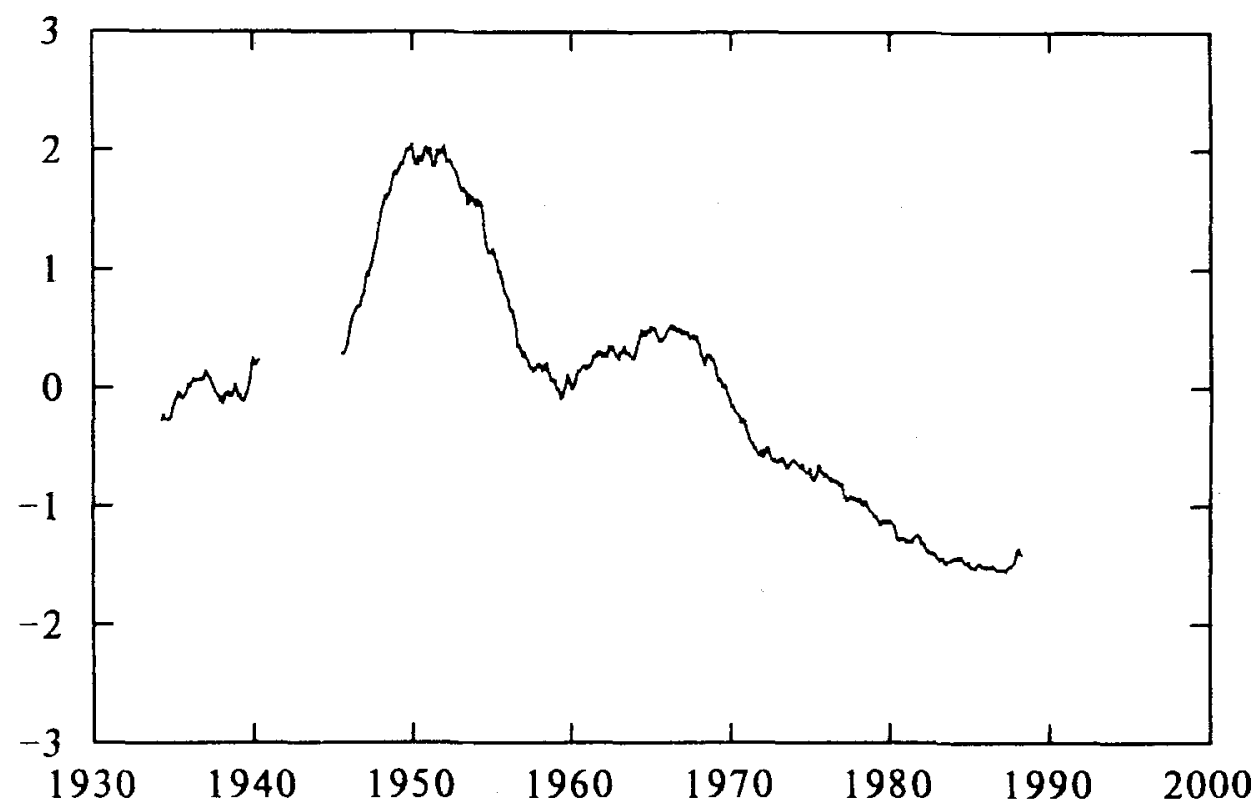

Fig. 1. The first principal component (explained variance is $53 \%$ ) from a PCA on the registration of 13 rare fish species caught in the Dutch sector of the North Sea between 1930 and 1990 (from de Vooys et al., 1991)

to fisheries is very limited. However, the short-term effects of beamtrawl fishing have been studied intensively. In 1984, de Groot concluded that beamtrawls with tickler chains seriously damage some groups of animals, e.g. echinoderms, possibly leading to longterm shifts in species composition and numbers (de Groot, 1984). More recently, an extensive Dutch study (BEON, 1990, 1991, 1992) led to the following conclusions:

- a commercial beamtrawl disturbs hard-sand sediment to a depth of at least $4-8 \mathrm{~cm}$;

- threefold trawling resulted in a statistically significant decrease in density (40-65\%) of starfish (Asterias rubens), small-sized heart urchins (Echinocardium cordatum) and the polychaete worms Lanice conchilega and Spiophanes bombyx. For small crustaceans, various bivalves and larger heart urchins, an insignificant decrease was found;

- the chance of survival for benthos, which is returned to the sea after the catch has been processed, is for Cancer and Arctica a low 10-15\%, for other molluscs and crabs not greater than $40 \%$, for starfish at least $70-80 \%$, and for whelks and hermit crabs approximately $100 \%$;

- all discarded fish returned to the sea after processing of the catch will die;

- in the study area, sole fisheries produced at least $5 \mathrm{~kg}$ discarded fish and $1 \mathrm{~kg}$ dead benthos per $\mathrm{kg}$ marketable sole.

Although these direct effects cannot be translated into long-term effects, one can imagine the possible changes in the ecosystem when the fishing intensity is taken into account. For the Dutch part of the North Sea, Welleman (1989) estimated the spatial distribution of the Dutch beamtrawl fishery for 1982 (Fig. 2A). Figure 2B gives the estimated distribution for 1990 . As a mean, every $\mathrm{m}^{2}$ of the Dutch part of the North Sea is 
trawled at least once a year. Several ICES rectangles are trawled 2-3 times per year, whereas for one rectangle a mean trawl density of 7 times per year was estimated. And these data only reflect the activities of the larger Dutch fishing vessels ( $>300 \mathrm{hp}$ ). Smaller vessels and other fleets are not included. It is clear that the sediment of the North Sea is frequently raked by the heavy beamtrawl gear with its tickler chains.

Rijnsdorp et al. (1991) described the spatial distribution of fishing efforts and concluded that vessels do not trawl at random but concentrate their efforts on restricted fishing grounds. For the five ICES rectangles studied, they concluded that in two rectangles the fishing was randomly distributed, whereas in three rectangles the fishing vessels involved trawled less than $60 \%$ of the available area. From this study, the patchy distribution of the beamtrawl effort is clear. But their conclusion that significant areas of the North Sea remain untrawled - giving refuge to the species of the benthic community most vulnerable for trawling - remains questionable. This was illustrated by our experiences in the Borkum Riff (BEON, 1992). The Borkum Riff is an area regarded by Dutch fisherman as one of the few places in the southern North Sea where beamtrawl

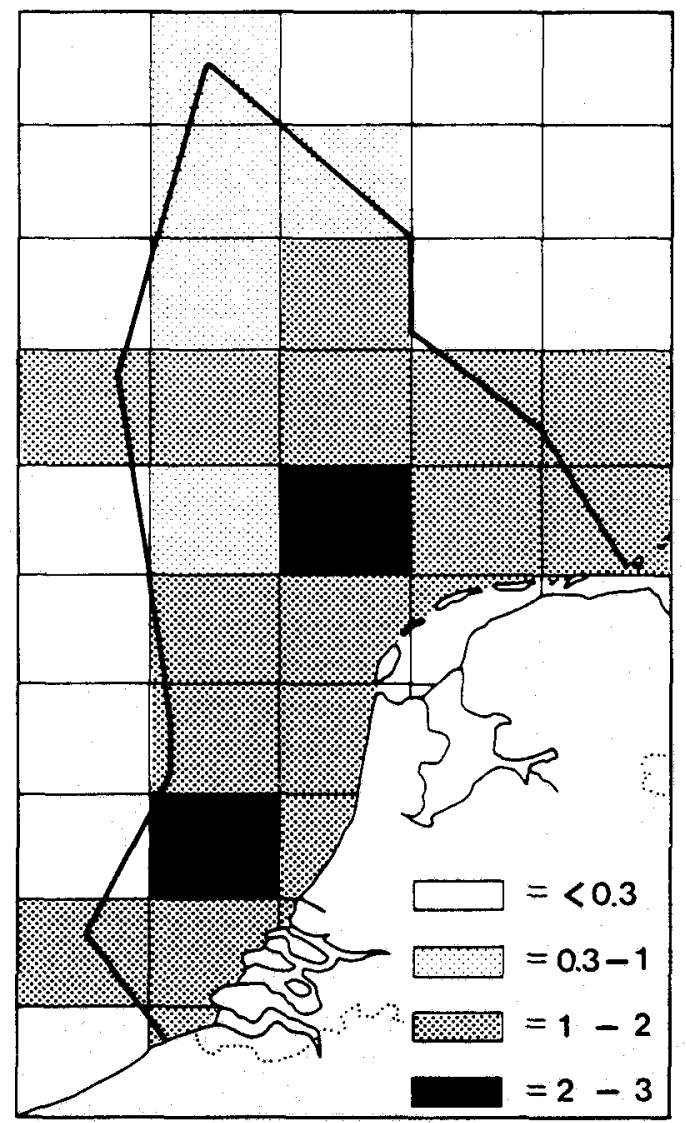

Fig. 2A. Registered minimum mean yearly trawling frequency by Dutch beamtrawlers $(>300 \mathrm{hp})$ in 1982 (data adapted from Welleman, 1989) 


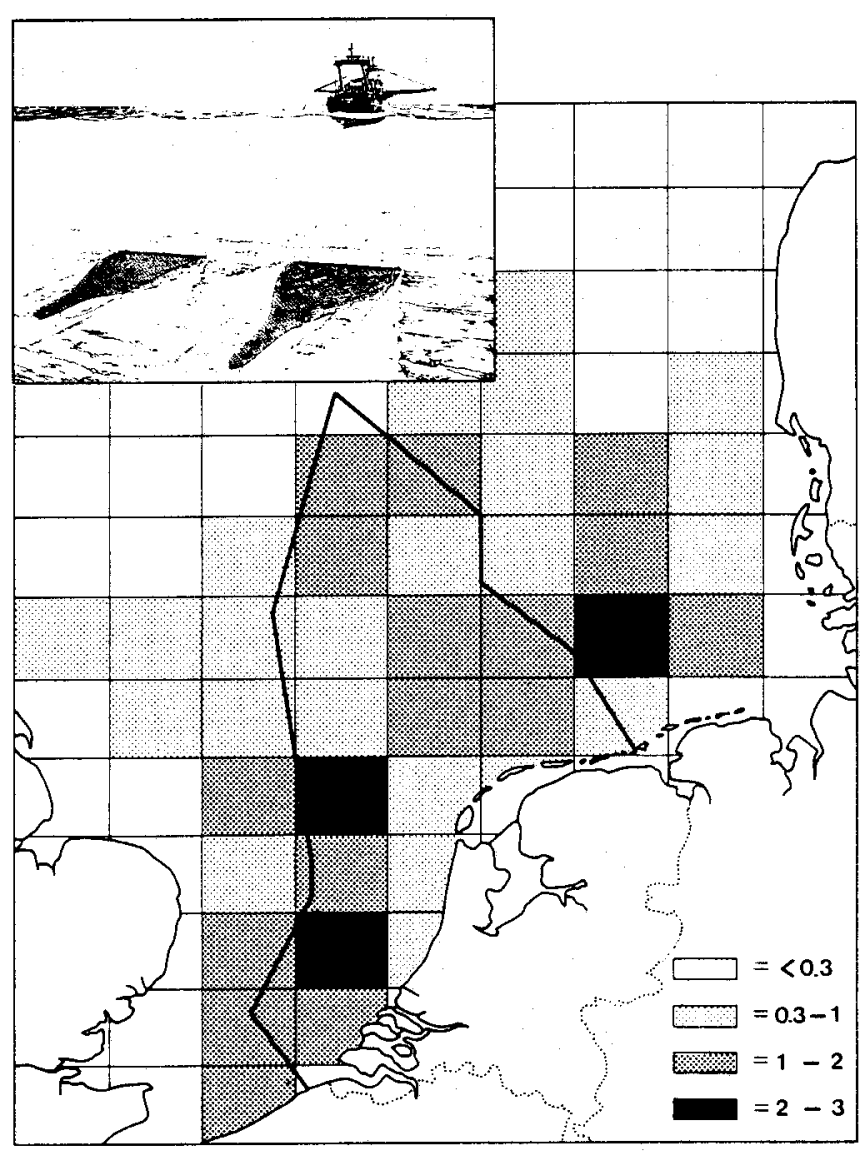

Fig. 2B. Trawling frequency by Dutch beamtrawlers, as in Fig. 2A, but for 1990 (data RIVO)

fishing is seriously hampered because of the presence of rocks in the Riff. However, when a side-scan sonar recording of the area (Fig. 3) was made, $70 \%$ of a 3-km transect was covered with trawl tracks, rendering the area unsuitable for the planned study on the long-term effects of beamtrawling. Attempts to discover other "untrawled" areas in the Dutch sector were unsuccessful. With present-day fishing techniques, it is very likely that all areas in the Dutch part of the North Sea where exploitable amounts of fish are found will be trawled regularly by the Dutch fishing fleet.

Bergman et al. (1991) concluded that there is hardly any place in the Dutch sector of the North Sea where benthic communities can develop undisturbed. It appears that a selection has taken place, from a diverse system to one where only fast-growing, good reproducing, smaller organisms can survive. The large, slow-growing bivalves are disappearing and are being replaced by worms. The slower-reproducing fish, such as sharks and rays, have more or less disappeared from larger parts of the North Sea; the big cods have gone, while a number of smaller, faster-growing species have increased.

Some bird species have increased in numbers, probably due to the fishing practices 


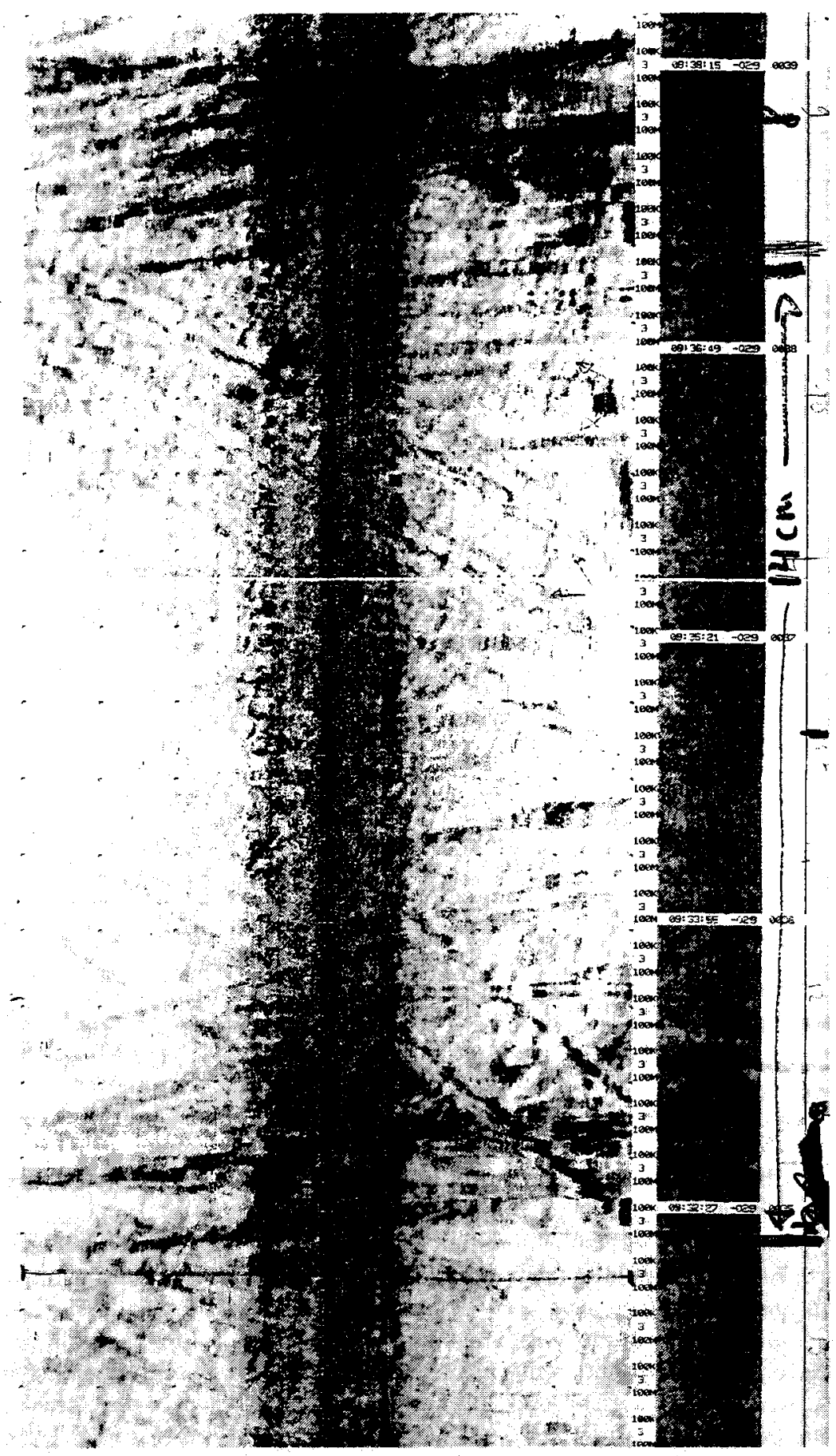

Fig. 3. Section of the transect in the Borkum Riff area inspected by side-scan sonar in August 1991 and showing many trawltracks (from BEON, 1992) 
(Dunnet et al., 1990), while the fisheries may have contributed to the decline of sea mammal populations (Reijnders \& Lankester, 1990).

There are many signals that the ecosystem has changed, and that fisheries have something to do with the change. However, hardly any conclusive scientific evidence exists for the cause-effect relationships.

The effects of the offshore industry in the Dutch sector of the North Sea have been demonstrated by Daan et al. (1990b; 1991). They found significant effects of the discharges of oil-based mud containing drill cuttings on the benthic fauna around drilling platforms. However, after the implementation of the 1992/94 ban on discharging oilbased muds into the marine environment it is unlikely that the oil and gas industry will continue to significantly influence the biota. So far, studies on the effects of water-based muds have not yielded any significant effects (Daan \& Mulder, 1993).

Sand and gravel extraction and the laying of pipelines and cables will result in local effects on the benthic system (Bergman et al., 1991). The long-term effects of these activities, as well as the effects of shipping and military activities, are not really known.

Recently, Boon \& ten Hallers found a high percentage of imposex-like phenomena in female whelks (Buccinum undatum) near the deep water shipping route on the Dutch Continental Shelf (ten Hallers et al., in press). Whether this is caused by tributyltin, as was demonstrated for dogwhelks (Nucella lapillus) (Bryan et al., 1986), is presently under investigation. On the other hand, fisheries might also influence the whelk population. The only way to establish whether fisheries significantly contribute to the observed phenomena seems to be by the creation of protected areas.

\section{PROTECTED AREAS FOR SCIENTIFIC RESEARCH}

Since fishing seems to be the major anthropogenic activity which influences the ecosystem and which can be controlled by establishing protected areas, we will focus on this activity. However, when protected areas are established, other activities, such as offshore industry, shipping, sand and gravel extraction and military exercises will also need some form of regulation.

There are various reasons for establishing protected areas for marine research. Recently, a biological monitoring programme was started in the Dutch sector of the North Sea (Duineveld, 1992). Benthic samples are taken annually at 25 sites and analysed for infauna and small epifauna. The aim is to establish possible trends in the development of this fauna during a period of 5-10 years. But what do these data mean if beamtrawls have ploughed the sampling area an unknown amount of times prior to the sampling? Or when in one year the area remained untouched by fisheries, whereas in another year, fishermen made it their favourite fishing area. The research on the direct effects of fisheries (BEON, 1990) indicates that the infauna and epifauna are easily influenced by fisheries on a short-term scale. Thus fisheries may influence the data collected in monitoring programmes, rendering these data useless for establishing possible trends caused by, for example, eutrophication or pollution. If trends, caused by actions other than fisheries, are to be monitored in the Dutch sector of the North Sea, the sampling sites should be offlimits to the fisheries. The results of several other scientific programmes knowingly, or more often unknowingly, may have been influenced by fisheries. Studies of the settlement and survival of benthic organisms, studies of sediment-water exchange or the 
transport of suspended matter, and even the benthic mapping executed by ICESmembers in 1986 (Künitzer et al., 1992) are possible examples.

Moored systems are used to measure the short-term variation in physical, chemical and/or biological parameters. In the Integrated North Sea Programme (INP), one of the projects is the deployment of a mooring, equipped with instruments provided by different countries and institutes. However, during the first year, several instruments (e.g. sediment traps) were lost from this mooring. The cause of the loss is most probably related to the passing of beamtrawl gear close to the mooring (Veth, pers. comm.). Other mooring programmes have had similar experiences. These programmes, which deploy very expensive equipment in the field for long periods of time, would benefit from the establishment of fishing-free areas. The size of protected areas for the purposes mentioned above could be rather small, e.g. $1 \mathrm{~km}^{2}$ for every sampling site. In these cases, the surface of a protected area would be determined by practical considerations on how to actually keep fisheries away from the area. If the area is too small, it is uncontrollable, and fishermen could reach the intended sampling site too easily. Thus an appropriately sized buffer zone around the $1 \mathrm{~km}^{2}$ would be needed.

Another purpose for protected areas are studies of the long-term effects of fisheries. As stated before, long-term changes in the underwater ecosystem have often been observed, and several of these seem to be related to the fisheries. But so far it has been impossible to indisputably identify cause-effect relationships. For example, the apparent disappearance of rays from the Dutch coastal zone (de Vooys et al., 1991) is most likely due to fisheries. But incontestable evidence is still needed. Comparisons between extensively fished and relatively unfished areas may provide such evidence, or give results which clearly reject the hypothetical relationship between fisheries and the occurrence of rays. Such research will even yield more conclusive results if a large fishing-free zone is created in a previously heavily-fished area. The size of such an area depends upon the species to be studied. For sessile benthos, such as the long-living shellfish, the area could be rather small, but considerable areas need to be closed off for migrating animals. There is a lot of experience with the establishment of reserves especially in tropical areas (Craik et al., 1990). However, these authors state that "the selection of sites usually owes more to the fact that they are not in demand for more obvious economic priorities than the intrinsic nature of the ecosystem".

Comparing the effects of fisheries with the effects of other anthropogenic influences will be a major task of applied scientific research. Especially when an economic recession forces governments to direct the available money to measures that will have the most effect for a sustainable development of the marine ecosystem, questions of what measures are most effective are being raised. Studies to answer these questions are becoming more and more important. However, as discussed before, it is almost impossible to quantitatively estimate the individual effects of fisheries, eutrophication and pollution in a given marine area. The establishment of a protected region in such an area may provide the practical means to study the effects of different anthropogenic activities.

From the above, it becomes clear that the establishment of protected areas is a prerequisite for scientific marine research in open-sea areas heavily influenced by human activities. This certainly applies to the Dutch area of the North Sea, and more than likely to several other oceanic areas too. However, there are more reasons for creating protected areas. 


\section{PROTECTED AREAS FOR NATURE CONSERVATION}

In the Netherlands, we conducted a study into the necessity and feasibility of the designation of protected areas in the Dutch sector of the North Sea as a contribution to the conservation and, where possible, rehabilitation of a natural diversity of ecologically valuable areas (Bergman et al., 1991). The objectives of such a designation would be:

- to preserve, rehabilitate and develop natural values by limiting the effects of human activities that cause detectable changes;

- to protect animals which are an integral part of the Dutch sector of the North Sea.

It is beyond the scope of this article to go into all the details of our study; therefore only the most important aspects will be mentioned.

First, we developed four criteria that may be used for the designation and selection of areas which qualify for a protected status. The first criterion addresses the extent to which specific activities have developed into a threat to the existence or normal functioning of groups of animals or species. The second criterion addresses the question whether a prohibition or restriction of certain human activities would reduce this threat. The third criterion is the use of ecological criteria, such as diversity, representativeness, integrity and vulnerability to identify the areas most suitable for protected status. Finally, the fourth criterion addresses the question of whether there are adequate legal instruments to ensure effective protection of the selected areas.

Taking into account the effects of different human activities described earlier in this article and on the basis of the above criteria, it was concluded that an area directly northwest of the Frisian Islands (Fig. 4) qualifies for protected status. In this area, containing coastal waters, sandy bottoms, the Frisian Front area, muddy areas and restricted stony areas, it would be possible to protect different types of benthic communities, including invertebrates and fish.

The following protective measures have been proposed for the area: (1) close the area to all types of fisheries throughout the year; (2) prevent or minimize oil-containing discharges from offshore mining installations; (3) take area-specific measures with respect to offshore mining, shipping, military activities, sand extraction, dumping and the laying of cables and pipelines whenever the situation in the area calls for such measures; (4) consider additional measures if the area is to be used as a reference area for scientific research.

Following the publication of Bergman et al. (1991), the Dutch government decided to take initiatives to establish a protected area in the Dutch sector of the North Sea in order to study the actual protective effects of such an area. A plan containing several alternatives will soon be sent to parliament. Because of the scale of the North Sea, it is desirable not to focus solely on the Dutch situation. However, since actual measures need to be implemented by the EC, it is likely that a more nationwide approach will be followed in the future.

In the North Sea, several protective measures have already been taken. A "plaicebox" and a "cod-box" were established in the eastern part of the North Sea to protect certain commercial fish species or their offspring (Bergman et al., 1991). The results obtained within and around the "plaice-box" indicate that fisheries might even benefit from protected areas. However, the actual measures within the boxes are not yet aiming at the protection of the ecosystem as a whole. 


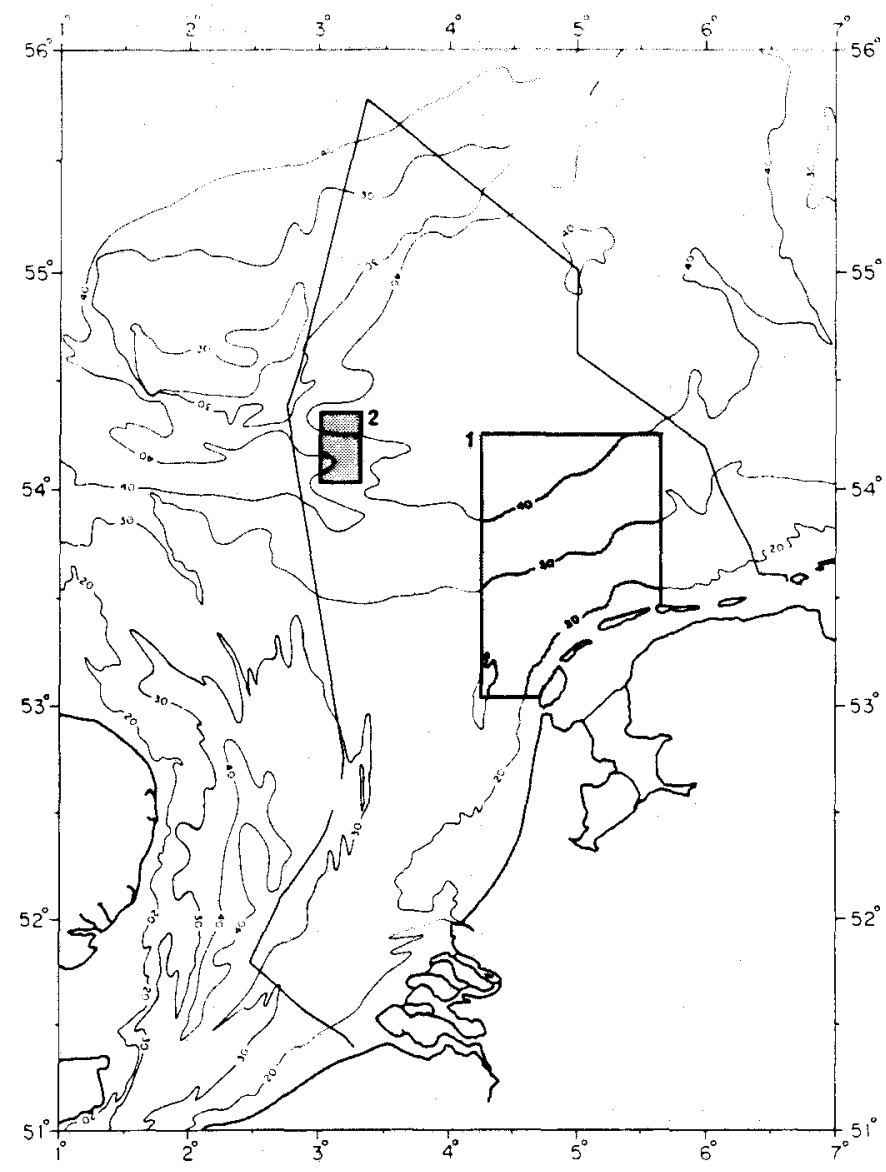

Fig. 4. Area within the Dutch sector of the North Sea qualifying for protected status (from Bergman et al., 1991)

\section{CONCLUSION}

From the above, it is clear that there are good reasons to create protected areas in the marine environment. Scientific research desperately needs them; nature conservation calls for them; and even fisheries might benefit from them. However, since the establishment of such areas in the open sea will demand the approval of the European Community, and because economics may be affected by the creation of fishing-free areas, a long and difficult political process lies ahead, throughout which sociocultural aspects will also have to be taken into account (Fiske, 1992). Only an approach that integrates the needs and possibilities of all managers, exploiters, and scientists involved will facilitate the successful creation of protected areas. In such areas an intensive research programme into the species composition, abundance and age distribution should be carried out, and trends should be established. 
Acknowledgements. The author would like to thank. Ir. M. J. N. Bergman and Dr. C. G. N. de Vooys for supplying data and figures. The technical staff of $\mathrm{NIOZ}$ are acknowledged for their help in preparing this manuscript. This is Publication No. 71 of the Department of Applied Research, Netherlands Institute for Sea Research (BEWON).

\section{LITERATURE CITED}

Aebisher, N. J., Coulsen, J. C., Colebrook, J. M., 1990. Parallel long-term trends across four marine trophic levels and weather. - Nature, Lond. 347, 753-755.

BEON, 1990. Effects of beamtrawl fishery on the bottom fauna in the North Sea. - BEON-Rapp. 8, $1-57$.

BEON, 1991. Effects of beamtrawl fishery on the bottom fauna in the North Sea. II.: The 1990 studies. - BEON-Rapp. 13, 1-85.

BEON, 1992. Effects of beamtrawl fishery on the bottom fauna in the North Sea. III.: The 1991 studies. - BEON-Rapp. 16, 1-27.

Bergman, M. J. N., Lindeboom, H. J., Peet, G., Nelissen, P. H. M., Nijkamp, H. \& Leopold, M.F., 1991. Beschermde Gebieden Noordzee - noodzaak en mogelijkheden. - NIOZ-Rapp. 1991-3, 1-195.

Bryan, G. W., Gibbs, P. E., Hummerstone, L. G. \& Burt, G. R., 1986. The decline of the gastropod Nucella lapillus around south-west England: evidence for the effect of tributyl-tin from antifouling paints. - J. mar. biol. Ass. U.K. 66, 611-640.

Corten, A., 1990. Long-term trends in pelagic fish stocks of the North Sea and adjacent waters and their possible connection to hydrographic changes. - Neth. J. Sea Res. 25, 227-235.

Craik, W. Kenchington, R. \& Kelleher, G, 1990. Coral-reef management. In: Coral reefs. Ed. by Z. Dubinsky. Elsevier, Amsterdam, 453-467.

Daan, N., 1989. The ecological setting of North Sea fisheries. - Dana 8, 17-31.

Daan, N., Bromley, P. J., Hislop, J. R. G. \& Nielsen, N. A., 1990a. Ecology of North Sea fish. - Neth. J. Sea Res. 26, 343-386.

Daan, R., Lewis, W. E. \& Mulder, M., 1990b. Biological effects of discharged oil-contaminated drill cuttings in the North Sea. - NIOZ-Rapp. 1990-5, 1-79.

Daan, R., Lewis, W. E. \& Mulder, M., 1991. Biological effects of washed OBM drill cuttings discharged on the Dutch continental shelf. - NIOZ-Rapp. 1991-8, 1-33

Daan, R. \& Mulder, M., 1993. A study on possible environmental effects of a WBM cutting discharge in the North Sea, one year after termination of drilling. - NIOZ-Rapp. 1993-16, 1-18.

Duineveld, G. C. A., 1992. The macrobenthic fauna in the Dutch sector of the North Sea in 1991. NIOZ-Rapp. 1992-6, 1-19.

Dunnet, G. M., Furness, R. W., Tasker, M. L. \& Becker, P. H., 1990. Seabird ecology in the North Sea. - Neth. J. Sea Res. 26, 387-425.

Fiske, F. J., 1992. Sociocultural aspects of establishing marine protected areas. - Ocean coast. Mgmt $18,25-46$.

Gerlach, S. A. 1990. Nitrogen, phosphorus, plankton and oxygen deficiency in the German Bight and Kieler Bay. - Kieler Meeresforsch. (Sonderh.) 7, 1-341.

Groot, S. J. de, 1984. The impact of bottom trawling on benthic fauna of the North Sea. - Ocean Mgmt 9, 177-190.

Künitzer, A., Basford, D., Craeymeersch, J. A., Dewarumez, J.-M, Dörjes, J., Duineveld, G. C. A., Eleftheriou, A., Heip, C., Herman, P., Kingston, P., Niermann, U., Rachor, E., Rumohr, H. \& Wilde, P. W. A. J. de, 1992. The benthic infaund of the North Sea: species distribution and assembläges. - ICES J. mar. Sci. 49, 127-143.

Lindeboom, H. J., 1989. Management of the seas: the North Sea. In: Nature management and sustainable development. Ed. by. W. D. Verwey. IOS, Amsterdam, 461-481.

Nielsen, A. \& Richardson, K., 1989. Chrysochromulina polylepis bloom in Danish, Swedish and Norwegian waters, May-June 1988 - an analysis of extent, effects and causes. - Wat. Pollut: Res. Rep. 12, 11-27.

Reijnders, P. J. H. \& Lankester, K., 1990. Status of marine mammals in the North Sea. - Neth. J. Sea Res. $26,427-435$. 
Rijnsdorp, A. D., Groot, P. \& Beek, F. A. van, 1991. The micro distribution of beam trawl effort in the southern North Sea. - C.M./ICES, G49, 1-20.

ten Hallers, C. C., Kemp, J. F. \& Boon, J. P., 1994. Imposex in whelks (Buccinum undatum) from the open North Sea: relation to shipping traffic intensities. - Mar. Pollut. Bull. 28 (in press).

Veer, H. W. van der, Creutzberg, F., Dapper, R., Duineveld, G. C. A., Fonds, M., Kuipers, B. R., Noort, G. J. van \& Witte, I. I. J., 1990. On the ecology of the dragonet Callionymus lyra L. in the southern North Sea. - Neth. J. Sea Res, 26, 139-150.

Vooys, C. G. N. de, Witte, I. I. J., Dapper, R., Meer, J. M. van der \& Veer, H. W. van der, 1991. Lange termijn veranderingen in zeldzame vissoorten op het Nederlands continentaal plat van de Noordzee. - NIOZ-Rapp. 1991-6, 1-81.

Welleman, H., 1989. Literatuurstudie naar de effecten van de bodemvisserij op de bodem en het bodemleven. - RIVO. MO 89-201, 1-58. 